\title{
STUDI KEBERADAAN BAKTERI PATOGEN PADA IKAN KAYU (Katsuwobushi) YANG DIPROSES DENGAN ASAP CAIR
}

\author{
Emeliza Kondangduata Pulu ${ }^{1}$, Henny Dien ${ }^{2}$, Joseffa Kaparang ${ }^{2}$ \\ ${ }^{1)}$ Mahasiswa pada Program Studi Teknologi Hasil Perikanan FPIK Unsrat Manado \\ ${ }^{2}$ Staf pengajar pada Program Studi Teknologi Hasil Perikanan FPIK Unsrat Manado \\ Email: emelizakondangduata_pulu@yahoo.com
}

\begin{abstract}
Sektor Perikanan tangkap telah menghasilkan beragam produk Perikanan karena didukung dengan luas wilayah tangkap dan keanekaragaman hasil penangkapannya. Ikan merupakan primadona sektor Perikanan tangkap dan diantaranya adalah Ikan Cakalang. Hasil pengolah an ikan Cakalang yang beraneka ragam serta rasanya yang khas menjadilkan Ikan ini diminati banyak orang. Teknik pengasapan sering dipakai dalam pengoalahan ikan Cakalang, yang dikenal dengan Cakalang fufu dan Ikan Kayu. Pengolahan Ikan kayu merupakan gabungan dari dua proses yaitu proses pengasapan dan pengeringan. Asap merupakan bahan pengawet alami. Senyawa kimia dari asap kayu umumnya berupa Fenol (yang berperan sebagai antioksidan), asam organik, alkohol, karbonil, hidrokarbon dan senyawa nitrogen seperti nitro oksida, aldehid, keton, ester, eter, yang menempel pada permukaan dan selanjutnya menembus ke dalam daging ikan, Isamu (2012). Pengasapan juga dapat menghambat kegiatan mikroorganisme hingga bermanfaat mengawetkan ikan, serta memberi aroma yang sedap, warna kecoklatan,tekstur yang bagus dan cita rasa yang khas pada daging yang diolah (Ananimous 2015) Ada beberapa jenis pengasapan yaitu pengasapan panas dan pengasapan dingin, ada pula pengasapan elektrik dan pengasapan cair. Penelitian ini bertujuan untuk mengamati dan menghitung keberadaan bakteri patogen yang dapat mengkontaminasi produk olahan hasil perikanan yaitu ikan kayu. Metode penelitian menggunakan metode eksperimental yang memberikan informasi berupa gambaran individu yang dapat mengkontaminasi ikan kayu, dengan rangkaian parameter uji meliputi Analisa Angka Lempeng Total, Pengujian Coliform dan Escherichia coli, Analisa total Staphylococcus, Analisa total Salmonella. Hasil Penelitian diperoleh Angka Lempeng Total terendah pada pengeringan awal $\left(1,3 \times 10^{4}\right)$, pengeringan akhir $\left(3 \times 10^{3}\right)$, Keberadaan Escherichia coli, Staphylococcus, Salmonella adalah negatif.
\end{abstract}

Kata Kunci: Ikan Cakalang Katsuwonus pelamis, Asap cair, Ikan Kayu.

\section{PENDAHULUAN}

Ikan adalah salah satu bahan pangan yang banyak dicari orang sehingga ikan menjadi primadona sektor Perikanan tangkap yang diantaranya adalah ikan Cakalang. Sifat hasil perikanan adalah cepat menjadi rusak dan busuk, hal ini disebabkan oleh karena daging ikan merupakan substrat yang baik untuk pertumbuhan mikroba pembusuk terutama bakteri (Hadiwiyoto, 1993). Pengolahan ikan yang baik adalah cara yang efektif untuk membuat ikan menjadi awet, sehingga berkembanglah metode pengolahan seperti penggaraman, fermentasi, pengeringan hingga pengasapan. Teknik pengolahan dengan metode pengasapan sering dipakai dalam pengolahan ikan Cakalang, dimana menghasilkan produk yang dikenal dengan Cakalang $f u f u$ dan Ikan Kayu. Hasil pengolahan ikan Cakalang yang beraneka ragam serta rasanya yang khas menjadikan ikan ini diminati banyak orang, hingga perusahaan yang berskala internasional berburu ikan ini untuk menjadikan produk olahan yang bernilai ekonomis tinggi.

Pengolahan Ikan kayu merupakan gabungan dari dua proses yaitu proses pengasapan dan pengeringan. Asap merupakan bahan pengawet alami didalamnya terdapat alkohol, aldehid, $\mathrm{CO}_{2}$ dan lain sebagainya (Adawyah, 2006). Ikan kayu memiliki struktur daging yang keras membuat produk ini awet (Zuraidah, 2014). Produk ikan kayu itu sendiri memiliki beberapa tahapan pengolahan, bila tingkat sanitasi dan kehigenisannya tak diperhatikan maka tak jarang produk terkontaminasi dengan mikroorganisme yang mengakibatkan penyakit pada manusia. Dalam Penelitian kali ini akan dilakukan pengamatan keberadaan bakteri Patogen, seperti Coliform dan Escherichia coli (E. coli), Salmonella sp serta Staphylococcus sp terhadap produk ikan kayu Katsuobushi yang menggunakan asap cair. 


\section{METODOLOGI PENELITIAN}

Metode penelitian ini menggunakan metode eksperimental yang memberikan informasi berupa gambaran/identifikasi mengenai suatu individu, keadaan, gejala berdasarkan fakta /kenyataan tentang mikroorganisme yang dapat mengkotaminasi produk olahan perikanan khususnya ikan kayu Cakalang (Katsuobushi) yang direndam dengan asap cair, dengan berbagai rangkaian seperti Analisis Angka Lempeng Total (ALT), Analisis Sataphylococcus sp, Analisis Salmonella sp, serta Analisis Coliform dan Escherichia coli.

\section{Tempat dan Waktu Penelitian}

Penelitian dilakukan di Laboratorium Teknologi Penanganan dan Pengolahan Hasil Perikanan dan Laboratorium Pengendalian Mutu Hasil Perikanan Fakultas Perikanan dan Ilmu Kelautan Universitas Sam Ratulangi, Manado. Penelitian dilaksanakan bulan September-Desember 2016.

\section{Alat dan Bahan}

Alat-alat yang digunakan dalam penelitian ini yaitu Autoclave, Alat Pengering, Bunsen, cawan petri, Inkubator, gunting, erlenmeyer, Jarum Ose, Desikator, Lampu, Oven, Pisau, Tabung Durham, Tabung Huss, Spritus, Spatula, pH meter, Timbangan, Pinset, Pipet skala $1 \mathrm{ml}$, Laminar air flow, dan Sarung tangan serta masker

Bahan yang di gunakan dalam penelitian ini adalah ikan Cakalang segar, ikan Kayu (Katsuobushi), Asap cair dari tempurung, akuades, Nutrien Agar (NA), Lactose Broth (LB), Manitol Salt Agar (MSA), Bismuth Salt Agar (BSA), Eosin Methylene Blue Agar (EMBA), NaCl, Alkohol 70 dan $95 \%, \mathrm{NaCl}$ 0,9 $\%$ dan tissue.

\section{Perlakuan}

Perlakuan yang digunakan dalam penelitian ini adalah:

(A) Konsentrasi Asap cair.

$$
\begin{aligned}
& \text { A1 }=1 \% \\
& \text { A2 }=2 \% \\
& \text { A3 }=3 \%
\end{aligned}
$$

(B) Lama Perendaman

$$
\begin{aligned}
& \text { B1 }=10 \text { menit } \\
& \text { B2 }=20 \text { menit } \\
& \text { B3 }=30 \text { menit }
\end{aligned}
$$

Tabel 1. Unit Percobaan

Konsentrasi Lama
Unit

\begin{tabular}{ccc}
\hline Asap Cair & Perendaman & Percobaan \\
\hline $1 \%$ & 10 menit & A1B1 \\
$1 \%$ & 20 menit & A1B2 \\
$1 \%$ & 30 menit & A1B3 \\
\hline $2 \%$ & 10 menit & A2B1 \\
$2 \%$ & 20 menit & A2B2 \\
$2 \%$ & 30 menit & A2B3 \\
\hline $3 \%$ & 10 menit & A3B1 \\
$3 \%$ & 20 menit & A3B2 \\
$3 \%$ & 30 menit & A3B3 \\
\hline
\end{tabular}

\section{Tata Laksana Penelitian}

\section{Tahapan Penelitian}

Adapun tahapan penelitian adalah sabagai berikut:

1. Pemilihan bahan baku ikan Cakalang segar dengan kisaran berat $0,5-1 \mathrm{~kg}$.

2. Pengambilan sampel awal untuk pengujian Angka Lempeng Total, Analisis Coliform dan Escherichia coli, Analisis Staphylococcus sp serta Analisis Salmonella sp.

3. Pembuatan asap cair

4. Penentuan Konsentrasi asap cair

5. Pengenceran asap cair 1, 2 dan $3 \%$

6. Pembuatan ikan kayu

7. Pengambilan sampel pada produk ikan kayu saat awal pengeringan dan pengeringan akhir, untuk pengujian Angka Lempeng Total (ALT), Analisis Coliform dan Escherichia coli, Analisis Staphylococcus sp dan Analisis Salmonella sp

\section{Diagram alir prosedur Penelitian}

Ikan Cakalang Segar

Pengambilan sampel untuk Analisis Angka Lempeng Total (ALT) Analisis Coliform dan Escheria coli, Analisis Staphylococcus sp, dan Analisis Salmonella sp

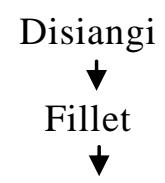

Direndam Pada konsentrasi Asap cair 1\%, 2\%, $3 \%$ Selama 10, 20 dan 30 menit

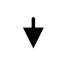

Keringkan dalam oven selama 1 jam dan jeda selama 2 jam, suhu $60-850 \mathrm{C}$

Pengambilan sampel untuk Analisis Angka Lempeng Total (ALT) Analisis Coliform dan Escheria coli, Analisis Staphylococcus sp, dan Analisis Salmonella sp 


\section{Ikan Kayu Asap Cair}

Pengambilan sampel untuk Analisis Angka Lempeng Total (ALT) Analisis Coliform dan Escheria coli, Analisis Staphylococcus sp, dan Analisis Salmonella sp

\section{HASIL DAN PEMBAHASAN}

\section{Angka Lempeng Total (ALT)}

Hasil penelitian untuk pengujian Angka lempeng Total pada ikan segar, pengeringan awal hingga pengeringan akhir produk ikan Kayu dengan menggunakan konsentrasi 1,2 dan $3 \%$ dan lama perendaman 10, 20 dan 30 menit yang menghasilkan 9 sampel unit percobaan dapat dilihat dalam tabel 2

Tabel 2. Data nilai TVB-N pada perlakuan jenis ikan dan lama penyimpanan.

\begin{tabular}{lccc}
\hline \multirow{2}{*}{ Sampel } & \multirow{2}{*}{ Unit Perlakuan } & \multicolumn{2}{c}{ Jumlah ALT } \\
\cline { 3 - 4 } Ikan Segar & & $1,3 \times 10^{3}$ & $5,5 \times 10^{4}$ \\
\hline \multirow{4}{*}{ Pengeringan } & A1B1 & $1,1 \times 10^{4}$ & $4,3 \times 10^{4}$ \\
pertama & A1B2 & $7,7 \times 10^{3}$ & $2,8 \times 10^{4}$ \\
& A1B3 & $4,5 \times 10^{3}$ & $1,4 \times 10^{4}$ \\
& A2B1 & $4,9 \times 10^{3}$ & $1,5 \times 10^{4}$ \\
& A2B2 & $4,2 \times 10^{3}$ & $1,3 \times 10^{4}$ \\
& A2B3 & $4,0 \times 10^{3}$ & $2,2 \times 10^{4}$ \\
& A3B1 & $5,3 \times 10^{3}$ & $1,2 \times 10^{4}$ \\
A3B2 & $4,2 \times 10^{3}$ & $1,5 \times 10^{3}$ \\
Pengeringan & A3B3 & $2,2 \times 10^{3}$ & $1,3 \times 10^{4}$ \\
\hline Akhir & A1B1 & $1,2 \times 10^{4}$ & $9,0 \times 10^{3}$ \\
& A1B2 & $3,8 \times 10^{3}$ & $7,0 \times 10^{3}$ \\
& A1B3 & $3,5 \times 10^{3}$ & $7,0 \times 10^{3}$ \\
& A2B1 & $3,1 \times 10^{3}$ & $9,0 \times 10^{3}$ \\
& A2B2 & $2,6 \times 10^{3}$ & $7,0 \times 10^{3}$ \\
& A2B3 & $3,7 \times 10^{3}$ & $1,0 \times 10^{4}$ \\
& A3B1 & $2,1 \times 10^{3}$ & $4,0 \times 10^{4}$ \\
& A3B2 & $1,9 \times 10^{3}$ & $5,0 \times 10^{3}$ \\
& A3B3 & $1,1 \times 10^{3}$ & $3,0 \times 10^{3}$ \\
\hline
\end{tabular}

Hasil Analisis Angka lempeng Total (ALT) pada ikan segar adalah $3,4 \times 10^{4}$ koloni/gram sampel pengeringan awal $7,6 \times 10^{3}$ koloni/gram sampel dan pengeringan akhir Angka Lempeng Total terendah adalah $2 \times 10^{3}$ koloni/gram sampel. Nilai Angka Lempeng Total di atas menunjukkan bahwa pada saat masih dalam bentuk ikan segar hingga telah menjadi produk ikan Kayu, jumlah mikroba yang terdapat dalam produk ini mengalami penurunan. Nilai tertinggi pada pengeringan awal berada pada konsentrasi $1 \%$ dengan perendaman 10 menit dengan nilai $4,3 \times 10^{4}$, hal ini dipengaruhi dengan tingkat konsentrasi dan perendaman selama 10 menit penetrasi asap cair ke dalam daging masih kurang maksimal jika dibandingkan dengan konsentrasi $3 \%$ lama perendaman 30 menit masih lebih rendah nilai mikroba yang ditunjukkan dengan nilai ALT $1,3 \times 10^{4}$, turunnya jumlah mikroba disebabkan juga karena penetrasi asap cair dan tingginya konsentrasi ke dalam daging ikan. Dibandingkan dengan SNI 01-2721-1992 menyatakan bawa batas toleransi untuk keamanan Ikan kayu adalah $1 \times 10^{4}$ koloni/gram sampel, sehingga ikan kayu yang diolah dengan konsentrasi 1,2 dan 3\% serta lama perendaman 10, 20 dam 30 menit berada jauh di bawah batas toleransi. Penurunan jumlah koloni tersebut dapat dilihat dalam Histogram rata-rata nilai Angka Lempeng Total (ALT) pada gambar
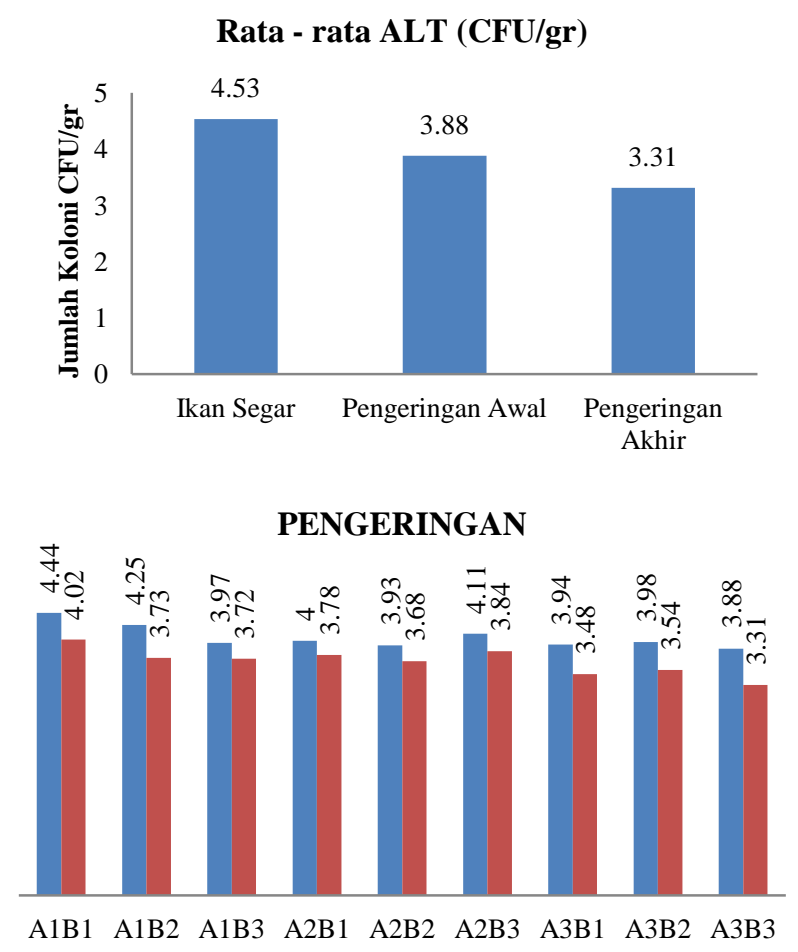

Menurut Hadiwiyoto (1993), tiap jenis mikroba mempunyai toleransi yang berbedabeda terhadap suhu, semakin tinggi suhu akan semakin sukar mikroba bertumbuh dan pada suhu tertentu akhirnya mati. Ikan kayu yang menggunakan asap cair dengan konsentrasi asap cair 1,2, dan 3\% serta lama perendaman 10, 20 dan 30 menit, menujukan bahwa adanya penurunan jumlah mikroba yang dipengaruhi oleh lamanya pengeringan. Pada pengeringan awal jumlah mikroba terendah ada pada konsentrasi asap cair $30 \%$ dengan lama pengeringan 30 menit menunjukan nilai $1,3 \times 10^{4}$ atau nilai lognya menjadi 3,88 hingga pengeringan akhir jumlah mikroba menjadi $3 \times 10^{3}$ atau nilai lognya menjadi 3,31 . Lamanya pengeringan membuat pertumbuhan mikroba semakin turun. Semakin sering pengeringan 
yang dilakukan maka tingkat pertumbuhan mikroba semakin rendah.

Penurunan jumlah mikroba yang menurun juga dikarenakan perlakuan konsentrasi yang berbeda dapat mengakibatkan penurunan yang drastis terhadap mikroba, semakin tinggi konsentrasi asap cair maka mikroba semakin berkurang, hal ini membuat produk Ikan kayu dengan perlakuan konsentrasi 3\% dan lama perendaman 30 menit memiliki nilai rata-rata terendah, sehingga kombinasi antara tingginya konsentrasi asap cair dan banyaknya jumlah pengeringan dapat menjamin menurunnya pertumbuhan mikroba dan membuat produk ikan kayu menjadi lebih awet.

\section{Analisis Coliform dan Escherichia coli}

Hasil Uji Pendugaan pada tahapan ini didapati hasil pada ikan segar dengan nilai MPN, di bawah ini.

Tabel 3: Hasil Pengujian MPN

\begin{tabular}{|c|c|c|c|c|}
\hline \multirow[b]{2}{*}{ Sampel } & \multicolumn{3}{|c|}{ Jumlah tabung positif } & \multirow{2}{*}{$\begin{array}{c}\text { AMP } \\
\text { per } \\
\text { gram } / \mathbf{m L}\end{array}$} \\
\hline & $10^{-1}$ & $10^{-2}$ & $10^{-3}$ & \\
\hline Ikan segar & 2 & 1 & - & 7 \\
\hline
\end{tabular}

Indikasi dengan perubahan warna media menjadi keruh, botol ini dinyatakan positif untuk dilakukan penghitungan dengan menggunakan tabel hopkin, dan didapati nilai MPN adalah 2-1-0, dengan nilai terendah adalah 7 , dengan hasil yang positif ini maka dilakukan pengujian peneguhan dengan media selektif EMBA, dengan metode gores. Hasil inkubasi didapati koloni berwarna hijau metalik sebanyak 2 koloni, dibandingkan dengan SNI ikan segar toleransi untuk kontaminasi Escherichia coli adalah $<3$, sehingga ikan segar yang digunakan dalam penelitian ini memiliki mutu baik.

Untuk ikan Kayu, hasil dalam uji pendugaan pada produk ikan kayu dengan metode MPN tidak ditemukannya perubahan warna dan tidak ada gelembung gas, hal ini menyatakan untuk pengujian MPN ikan Kayu hasilnya negatif sehingga tidak dilakukan pengujian Peneguhan.

\section{Analisis Total Staphylococcus sp}

Hasil Analisis Staphylococcus pada ikan segar yang dilakukan dengan uji pendugaan dengan media Lactose broth dan metode MPN didapati data $10^{-1}$ : 2, pada $10^{-2}$ adalah 1 , dilakukan pengujian peneguhan yang menggunakan media Manitol Salt Agar (MSA) dengan metode penggoresan kemudian diinkubasi 1x24 jam, namun tidak ditemukan adanya pertumbuhan koloni Staphylococcus sp.

Pengeringan awal dan pengeringan akhir yang juga dilakukan pengujian pendugaan dan peneguhan dengan menggunakan media yang sama namun tidak didapati adanya pertumbuhan koloni staphylococcus sp. SNI 01 2721-1992 menyatakan syarat mutu ikan Asap yang memiliki toleransi Staphylococcus. Sp (MPN/gr MAKS) sebanyak $1 \times 10^{-3}$, sehingga keberadaan Staphylococcus. sp pada produk ikan Kayu dengan Konsentrasi 1, 2 dan 3 dengan perendaman 10, 20 dan 30 menit adalah negatif.

\section{Analisis Salmonella sp}

Hasil pendugaan dengan media Lactose broth dengan metode MPN pada pada ikan segar didapati hasil yaitu: $10^{-1}: 2$ dan $10^{-2}: 1$ atau $2,1,0$.

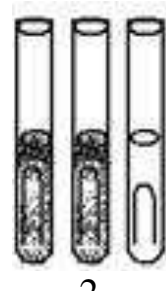

2

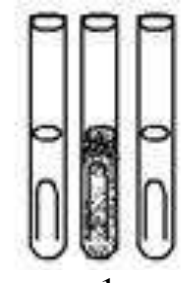

1

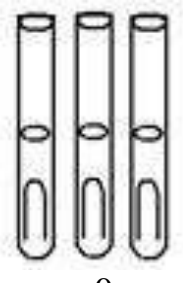

0
Uji Pendugaan

sehingga dilakukan uji peneguhan dengan menggunakan media Bismuth salt Agar (BSA), yang diinkubasi selama 1x24 jam, dilanjutkan dengan pengamatan. Sampel yang dinkubasi tidak ditemukan adanya pertumbuhan koloni, sehingga pada ikan segar Salmonella sp adalah negatif.

SNI 2729:2013 untuk ikan segar menyatakan bahwa toleransi untuk Salmonella sp (MPN/grMaks) adalah negatif/25g. Pada proses pengeringan awal hingga menjadi ikan kayu, hasil yang didapat adalah negatif. Pengeringan yang menggunakan suhu tinggi secara berulang-ulang dapat menyebabkan kerusakan pada mikroorganisme termasuk Salmonella sp, sehingga pada pengujian keberadaannya di produk ikan Kayu dengan konsentrasi 1, 2 dan $3 \%$ dengan lama perendaman 10, 20 dan 30 menit hasilnya adalah negatif.

SNI 01-2721-1992 yang digunakan sebagai pembanding menyatakan jumlah toleransi untuk Salmonella sp (MPN/gr maks) adalah negatif hal ini menyatakan bahwa 
produk ikan kayu yang menggunakan konsentrasi 1, 2, dan 3\% dengan lama perendaman 10, 20 dan 30 menit bebas dari kontaminasi Salmonella sp sehingga aman untuk dikonsumsi.

\section{KESIMPULAN DAN SARAN}

\section{Kesimpulan}

1. Hasil uji nilai Angka Lempeng Total (ALT) Ikan Kayu yang menggunakan dengan konsentrasi asap cair 3\% selama 30 menit memiliki jumlah mikroba terendah dengan nilai $3 \times 10^{3}$, dengan nilai $\log 3,31$ hal ini dikarenakan tingginya konsentrasi asap cair, lamanya perendaman dan pengeringan.

2. Pengujian Ikan Kayu 1, 2 dan 3\% serta lama perendaman 10, 20 dan 30 untuk mikroba Staphylococcus sp, Salmonella sp serta Coliform dan Eschericia coli menggunakan metode MPN dengan uji pendugaan dan peneguhan didapati hasil adalah negatif.

\section{Saran}

Penelitian terhadap Ikan Kayu dengan konsentrasi 1,2 dan $3 \%$ dengan lama pengeringan 10,20 dan 30 menit dibutuhkan pengujian lanjut.

\section{DAFTAR PUSTAKA}

Adawyah, R.M.P., 2007. Pengolahan dan pengawetan Ikan. Bumi Aksara. Jakarta

Afrianto, E., dan Liviawaty, E. 1989. Pengawetan dan Pengolahan ikan. Kanisius. Jakarta

Andini, L.S, Harsojo, Rosalina,S.H dan Purnomo,S., 1996. Sensitivitas Isolat Salmonella sp. Terhadap Radiasi, Suhu dan pH. Jurnal Penelitian. Bogor

Ayudiarti, D. L., dan Sari, R. N., 2010. Asap Cair dan aplikasinya pada produk perikanan asap. Jurnal Perikanan

Anonimous, 2002., Jurnal Litbang Pertanian 21(3)

Anonimous, 2004. Poeloengan, M., Bahaya Salmonella terhadap kesehatan, Jurnal Kesehatan.

Anonimous, 2007., Faridz, R. Hafiludiddin dan Anshari.M., Analisis Jumlah Bakteri dan keberadaan Eschericia Coli pada pengolahan Ikan Teri nasi di PT. Kelola Mina Laut Unit Sumenep. Jurnal Penelitian. 4(2). ISSN 0216-0188

Anonimous, 2008., Jurnal Pengujian Mikrobiologi Pangan, Badan Pengawas Obat dan Makanan Republik Indonesia, ISSN 1829 - 9334.

Anonimous, 2014., Identifikasi dan Karakteristik Staphylococcus sp dan Streptococcus sp dari infeksi Ovarium pada Ayam Petelur Komersial. Jurnal Ilmu Ternak. 1. No 7,32-37
Badan Standarisasi Nasional, 1992. Dewan Standart Nasional tentang Mutu Ikan Kayu , SNI 01-27101992

Badan Standarisai Nasional, 2006. Cara Uji Mikrobiologi - Bag - 2 : Penentuan Salmonella pada produk perikanan. SNI 01 2332. 2 -2006

Badan Standarisasi Nasional, 2013. Ikan Segar. SNI 2729: 2013

Buckle, K.A. R.A Edwards, G.H Fleet and M. Wooton, 1987. Ilmu Pangan. Penerjemah Hari Purnomo Adiono. Penerbit Universitas Indonesia. (UI Press). Jakarta.

Dundu, B., 1986. Flora Bakteri Pada Ikan Cakalang (Katsowonus pelamis, L) dan Produk-produknya di Sulawesi Utara. Laporan Penelitian. UNSRAT. Manado

Fardiaz, S., 1983. Keamanan Pangan. Jilid 1 Bakteriologi Jurusan Ilmu dan Teknologi Pangan. Fakultas Teknologi Pertanian. Institut Pertanian Bogor

Fardiaz, S., 2002. Pengaruh Jenis Kapang Dan Lama Fermentasi Terhadap Mutu Ikan Kayu (Katsuobushi) Cakalang. Jurnal Hasil Penelitian. Bul.TeknoL dun lndustri Pangan,9(2)

Heruwati. E. S., 2002. Pengolahan Ikan Secara Tradisional: Prospek Dan Peluang Pengembangan. Jurnal

Hadiwiyoto.S., 1993. Teknologi Pengolahan Hasil Perikanan jilid 1. Liberty. Yogyakarta

Ijong F.G., 2013. Penuntun Praktikum Mikrobiologi. Perikanan dan Kelautan. Fakultas Perikanan dan Ilmu Kelautan. UNSRAT. Manado.

Ijong. F.G., 2015., Mikrobiologi Hasil perikanan. Rineka Cipta, Jakarta

Igirisa, Y. 2006. Salmonella pada Ikan Tuna (Thunnus albacores) Loin Beku Dari PT. Nutrindro Fresh Food International. Skripsi. Fakultas Perikanan dan Ilmu Kelautan. UNSRAT. Manado.

Irianto., 2006. Mikrobiologi. Jilid 2. Peracun makanan oleh Staphylococcus. CV. Yrama Widya.,Margahayu Permai Bandung

Isamu, T, K. Purnomo, H,. Sudirmanto,S, Y., 2012. Karakteristik Fisik, Kimia, Dan Organoleptik Ikan Cakalang (Katsuwonus pelamis) Asap di Kendari. Jurnal Teknologi Pertanian 13 (2),105-110

Kaparang. R., Harikedua.D, S., Suwetja.K.I., 2013 Penentuan Mutu Ikan Tandipang (Dussumieria Acuta C.V) Asap Kering Selama Penyimpanan Suhu Kamar., Jurnal Media Teknologi Hasil Perikanan 1(1).

Karimela, E.J. 2013. Staphylococcus sp. Pada Ikan Layang (Decapterus ruselii) Asap Pinekuhe Produk khas Sangihe. Skripsi. Fakultas Perikanan dan Ilmu Kelautan. UNSRAT. Manado

Liviawaty. E, dan Afrianto E., 2010. Penanganan Ikan Segar., Widia Padjajaran. Bandung

Liviawaty. E., Afrianto,E., 2014. Penentuan Waktu Rigor Mortis Ikan Nila Merah (Oreochromis Niloticus) Berdasarkan Pola Perubahan Derajat Keasaman. Laboratorium Teknologi Industri Hasil Perikanan Fakultas Perikanan dan Ilmu Kelautan Universitas Padjadjaran. Bandung Jurnal Akuatika. 
Lumi, W, K,. Mantjoro, E,. Wagiu, M., 2013. Nilai Ekonomi Sumberdaya Perikanan Di Sulawesi Utara (Studi Kasus Ikan Cakalang, (Katsuwonus pelamis). Jurnal Ilmiah Platax, 1-2, ISSN :2332- 3589

Prtiwi. E. A., 2008.Pernetapan HACCP (Hazaard Analitic Critical Control Point) Pada pengolahan Ikan Kayu di PT. Etmieco Sarana Laut Bitung. Skripsi. FakultasPerikanan dan Illmu Kelautan. UNSRAT. Manado.

Pundoko, S. S., Onibala, H., Agustin, T, A., 2014. Perubahan Komposisi Zat Gizi Ikan Cakalang (Katsuwonus Pelamis L.) Selama Proses Pengolahan Ikan Kayu. Jurnal Media Teknologi Hasil Perikanan $1(2)$.

Sahetapy Meilany., 2005. Kapang pada fillet ikan Cakalang (Katsuwonus pelamis, L.) Yang Diasapi dengan Asap cair dan dikemas Vakum. Skripsi. Fakultas Perikanan dan Ilmu Kelautan. UNSRAT. Manado.

Suwetja. I.K., Biokimia Hasil Perikanan, 2011, Media Prima Aksara, Jakarta.

Tapatubun,1., 2000. Hubngan Kadar air dengan Mutu Ikan. https//daniwara.wordpress.com/laporan-tfpp. Laporan TFPP

Wibowo. S., 2000. Industri Pengasapan Ikan, Penebar swadaya. Jakarta.

Zuraidah, S., 2014. Tesis Strategi Pemasaran Produk Ikan Kayu (Arabushi) Di Kota Banda Aceh. Program Pascasarjana. Universitas Hasanuddin, Makassar. 